\title{
Differentiation of Crypt Epithelium in Human Palatine Tonsils: the Microenvironment of Crypt Epithelium as a Lymphoepithelial Organ
}

\author{
Yoko SATO ${ }^{1}$, Kenjiro WAKE ${ }^{2}$ and Isamu WATANABE ${ }^{1}$ \\ Departments of Otolaryngology ${ }^{1}$ and Anatomy ${ }^{2}$, Faculty of Medicine, Tokyo Medical and Dental University, Tokyo, Japan
}

Received March 29, 1989

\begin{abstract}
Summary. The differentiation of the keratinocytes of the human palatine tonsils were studied by means of light and electron microscopy and immunohistochemistry using a polyclonal $(K)$ and two monoclonal antikeratin antibodies (PKK1, PKK2). In the surface epithelium, the basal cells, cuboidal or columnar in shape, undergo progressive terminal differentiation and are transformed into the flattened cells of the upper layers. $K$ reacts with both the basal and spinous layers, while PKK1 and PKK2 mark exclusively the basal layer. In the neck portion of the crypt, cavities containing one or aggregated lymphocytes with amorphous substances are observed in the spinous layer. The cavities are surrounded by elongated cytoplasmic processes of transformed epithelial cells bearing surface microvilli. These transformed epithelial cells display intense PKK1- and PKK2-positive reactions, whereas other conventional polygonal cells in the vicinity remain PKK1- and PKK2negative as do those in the surface epithelium. In the deep portion of the crypt, where numerous lymphocytes invade the epithelium, the epithelial cells are transformed into star-shaped reticulum cells showing PKK1- and PKK2-positive reactions. The extended and branched cytoplasmic processes interconnect with one another constituting a complex network of reticulum cells, the well known reticulation of the crypt epithelium. Ten-nm filaments are usually oriented parallel to the longitudinal axis of transformed epithelial cells. Our observations suggest that the cell-shape transformation, i.e., from conventional polygonal epithelial cells into epithelial reticulum cells, occurs when the epithelial cells are in close contact with the infiltrating lymphocytes, and that this transformation is accompanied by a change in keratin phenotype.
\end{abstract}

Lymphoid organs can be classified into two major groups: lymphoepithelial and lymphovascular organs. The palatine tonsils, thymus and Peyer's patches belong to the lymphoepithelial organs. The formation of deep crypts is one characteristic of the palatine tonsils. In human fetuses at about 16 weeks gestation, epithelial crypts invaginate into the connective tissue and are infiltrated with lymphocytes (VON GAUDECKER and MÜLLER-HERMELINK, 1982). The crypt epithelium, which represents the T-cell region as well as the interfollicular area of the palatine tonsils (YAMANAKA et al., 1983; VON GAUDECKER et al., 1984), plays an important role as an immunobarrier in the upper respiratory and digestive pathways (BRANDTZAEG, 1988). Recent studies have revealed that a specific microenvironment of the thymus is essential for the maturation of T-cells (HAYNES, 1984; KYEWSKI, 1986; WEISSMAN, 1986). Thymic nurse cells (WEKERLE et al., 1980; RITTER et al., 1981; VAN DE WIJNGAERT et al., 1983; DE WAAL MALEFIJT et al., 1986; LEENE et al., 1988), and various subtypes of thymic epithelial cells (VAN DE WIJNGAERT et al., 1984; NICOLAS et al., 1985, 1986; USHIKI, 1986; VON GAUDECKER et al., 1986; KENESHIMA et al., 1987) have been demonstrated. Currently, the epidermis is recognized as sites of immune responses, and interactions between lymphocytes and keratinocytes through keratinocyte-derived cytokines and Interferons have been suggested (LUGER et al., 1981, 1985; MIOSSEC et al., 1984; DUSTIN et al., 1986, 1988; KUPPER et al., 1986; HANCOCK et al., 1988; SHIOHARA et al., 1988). However, the microenvironment of the tonsillar crypt epithelium, i.e., the morphological and functional relationship between the crypt epithelium and lymphocytes, is at present poorly understood.

The cells forming the crypt epithelium are rich in cytokeratin filaments which belong to intermediate filaments or 10-nm filaments, a complex family of dif- 
ferent polypeptides (MOLL et al., 1982; CoOPER et al., 1985; QUINLAN et al., 1985). Therefore, an immunohistochemical examination for cytokeratin is a useful tool for morphological studies of the crypt epithelial cells. For this reason, cytokeratin immunohistochemistry has been applied to studies on keratin expression in the epithelial cells during differentiation (FUCHS and GrEEN, 1980; WoODCOCK-Mitchell et al., 1982; TSENG et al., 1982), neoplastic changes (OSBORN and WEBER, 1983; HOLTHÖFER et al., 1983), ontogenic development (HOLTHÖFER et al., 1984; GUSTAFSSON et al., 1988; KASPER et al., 1988; VIEBAHN et al., 1988), cell-cell contacts and intercellular communication (BEN-ZE'Ev, 1984). However, there have so far been no reports on keratin expression during the differentiation of the epithelium of the palatine tonsils.

The present light and electron microscope study used immunohistochemistry to focus attention on the differentiation of epithelial cells during the infiltration of lymphocytes in the human palatine tonsils. The microenvironment of the crypt epithelium as one of the lymphoepithelial organs, and the possibility of the lymphoepithelial interaction will be discussed.

\section{MATERIALS AND METHODS}

Human palatine tonsils were obtained from nine children (aged 5-12 years) and two young adults (aged 18 and 22 years) undergoing tonsillectomy for recurrent tonsillitis $(n=7)$, otitis media with effusion $(n=$ 2 ), and tonsillar hypertrophy $(n=2)$. For routine lightmicroscopic histology, specimens were fixed in $10 \%$ formalin. Paraffin serial sections, $5 \mu \mathrm{m}$ in thickness, were stained with hematoxylin and eosin.

\section{Immunohistochemistry}

For the immunohistochemical study, 5-mm-thick tissue slices were cut perpendicular to the tonsillar surface, and fixed in $99.5 \%$ ethanol, or $10 \%$ formalin for 4 days at $4^{\circ} \mathrm{C}$ (ALTMANNSBERGER et al., 1981; HUITFELDT and BRANDTZAEG, 1985). They were then dehydrated, and embedded in paraffin. Sections $5 \mu \mathrm{m}$ in thickness were stained with antikeratin antibodies using the avidinbiotin peroxidase complex (ABC) method (NAKANE, 1975; HSU et al., 1981). Protease treatment was not employed, but the elimination process of endogenous peroxidase was performed. Some pieces of the tonsils were frozen in liquid nitrogen immediately after surgery and stored in $-80^{\circ} \mathrm{C}$ refrigerator until use. $5 \mu \mathrm{m}$ cryostat sections were subjected to the $\mathrm{ABC}$ method.

The sources of antikeratin antibodies used in this work and the molecular weight of corresponding cyto- keratin antigens were as follows: 1) $\mathrm{K}$ (Dakopatts, Santa Barbara, USA, Catolog No. A575, polyclonal, 48,000-67,000 daltons); 2) PKK1 (Labsystems, Helsinki, Finland, Catalog No. 6400201, monoclonal, 40,000, 45,000, 52,500 daltons); 3) PKK2 (Labsystems, Helsinki, Finland, Catalog No. 6400211, monoclonal 40,000, $46,000,54,000$ daltons). $\mathrm{K}$ was raised in rabbits by immunization with purified keratin proteins isolated from human epidermis. It reacted with all except the superficial layer of the human epidermis and oral mucosa (SCHLEGEL et al., 1980; HOSAKA et al., 1985). PKK1 and PKK2 were raised in mice against cytoskeletal proteins isolated from a pig kidney cell line. According to Moll's classification (MoLL et al., 1982), PKK1 reacted with cytokeratins No. 19, 18, 8 and PKK2 with cytokeratins No. 19, 17, 7, respectively (HOLTHÖFER et al., 1983, 1984; VIRTANEN et al., 1985; MURASE et al., 1986; GUSTAFSSON et al., 1988).

\section{Light and transmission electron microscopy}

Small slices, $2 \mathrm{~mm}$ thick, were cut perpendicular to the tonsillar surface and fixed for $2.5 \mathrm{~h}$ in $0.065 \mathrm{M}$ cacodylate-buffered $1.5 \%$ glutaraldehyde ( $\mathrm{pH}$ 7.4) containing $1 \%$ sucrose. After postfixation in $0.1 \mathrm{M}$ phosphate-buffered $1 \%$ osmium tetroxide, the tissues were dehydrated in ascending grades of ethanol and embedded in Poly/Bed 812. Semithin sections $0.5 \mu \mathrm{m}$ thick were prepared using glass knives. The sections were stained with toluidine blue for light microscopy.

Silver-gold ultrathin sections were cut using a diamond knife, double contrasted with uranyl acetate and lead citrate, to be examined in a JEOL-100CX transmission electron microscope with an accelerating voltage of $100 \mathrm{kV}$.

\section{RESULTS}

\section{General organization of human palatine tonsils}

The palatine tonsil is covered by a noncornified stratified squamous epithelium. The overlying epithelium invaginates into the deep tonsillar crypts (Fig. 1). Three principal layers, basal, spinous, and superficial, are identified in the surface epithelium (Fig. 2). These three cannot be clearly identified in the crypt epithelium because of the infiltrating lymphocytes (Fig. 3). In the surface epithelium the cells of the superficial layer display pyknotic nuclei, and the basal cells are low and columnar (Fig. 2). The basal cells of the crypt epithelium, in contrast, are cuboidal or bell-shaped. A few lymphocytes are scattered in the surface epithelium, whereas in the neck portion of the crypt more 
numerous lymphocytes aggregate to form nests (Fig. 3 ). In the deep portion of the crypt, a large number of lymphocytes invade the dilated intercellular spaces of the epithelial reticulum cells. The crypt epithelium does not penetrate into lymphoid follicles but invades interfollicular areas (Fig. 1). The boundary between the epithelium and underlying lymphoid tissue is obscure in hematoxylin-eosin preparations.

\section{Immunohistochemistry}

The reaction pattern in the ethanol- or the formalinfixed sections was equivalent to that in the frozen sections, although the frozen sections showed the best reaction sensitivity, that of the ethanol-fixed material was next, while relatively poor staining occurred in the formalin-fixed ones. We mainly examined the ethanolfixed preparations, since they gave well-preserved histological structures and an excellent reaction sensitivity.

In the surface epithelium of the palatine tonsils, $\mathrm{K}$ reacted with the cytoplasm of the cells in the entire basal and spinous layers. Particularly, the upper cell layers of the spinous layer were strongly stained with $\mathrm{K}$ (Fig. 2). The reaction was missing in the superficial layer. The apical and infranuclear cytoplasm of the basal cells was densely colored by the reaction product. In the neck portion of the crypt, $\mathrm{K}$ reacted with the cells of all epithelial layers, similar to the situation in the surface epithelium (Fig. 3). The superficial 1-4 cell layers reacted strongly with $\mathrm{K}$. Even in the deep portion of the crypt, the boundary between the epithelium and the underlying lymphoid tissue was clearly depicted in $\mathrm{K}$-treated preparations, since $\mathrm{K}$ reacted only with the epithelium and no reaction occurred in the lymphoid tissue.

The immunoreactivity to PKK1 of the crypt epithelium markedly differed from that of the surface epithelium as shown in Figure 1. In the surface epithelium, PKKl reacted predominantly with the basal layer, and no reaction could be found in the suprabasal layers (Fig. 4). In the basal layer cells, basal and supranuclear portions of the cytoplasm displayed intense reactions. In the neck portion of the crypt, the reaction of the basal layer was weak, while some of the epithelial cells in the spinous layer, which adjoined infiltrating lymphocytes, stained intensely with PKK1 (Figs. 5-7). A small amount of amorphous material was inserted between PKK1-positive cells and lymphocytes. A cavity was found surrounding the nest of infiltrating lymphocytes, and epithelial cells stained with PKK1 were star-shaped displaying long cytoplasmic processes which surrounded the cavity

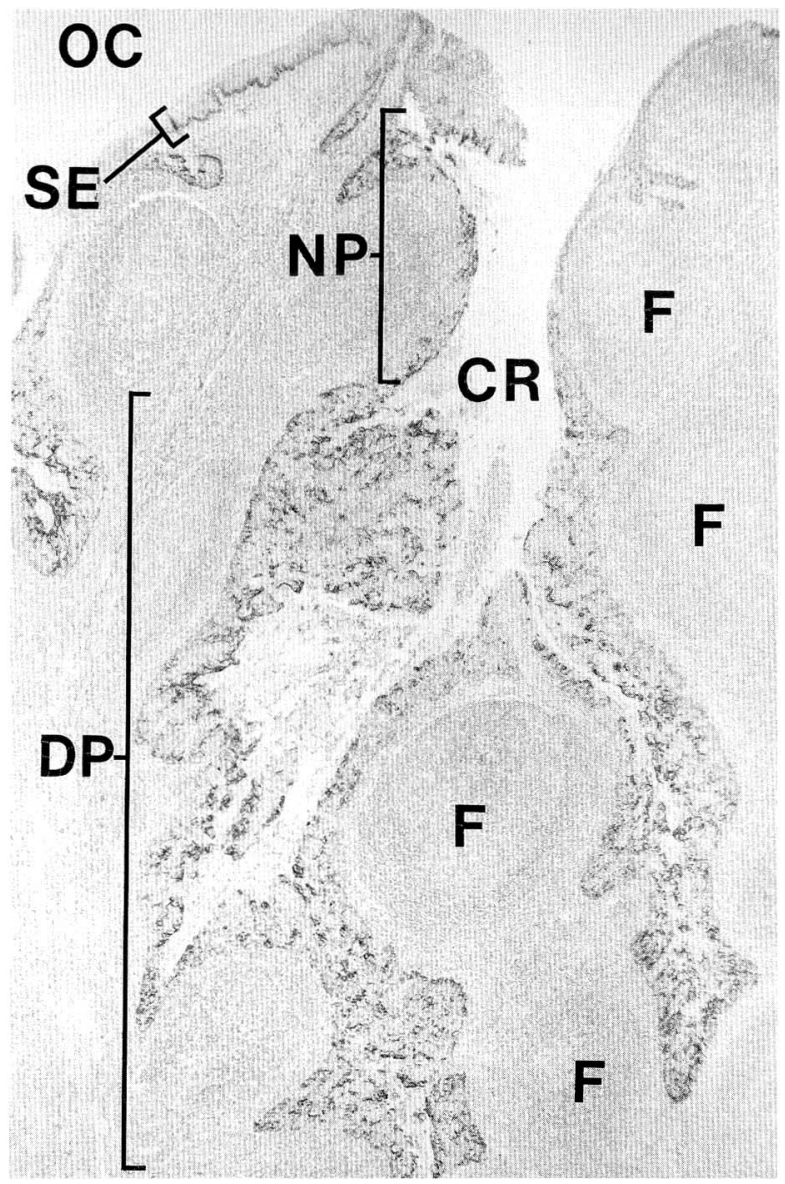

Fig. 1. A low magnification view of a portion of the human palatine tonsil; immunohistochemical reaction with PKK1, a monoclonal antikeratin antibody. The epithelial tissue displays three zones due to differences in staining patterns: surface epithelium $(S E)$, neck $(N P)$ and deep portions $(D P)$ of the crypt $(C R)$, which penetrate deeply into the interfollicular area. $F$ lymphoid follicle, $O C$ oral cavity. ABC method. $\times 30$

(Figs. 10, 11). In the deep portion of the crypt, numerous lymphocytes infiltrated the crypt epithelium, and the number of strongly immunoreactive epithelial cells increased. The cells immunoreactive to PKK1 were distributed in an area extending from the base to the surface of the crypt epithelium. The epithelial reticulum cells strongly reactive to PKK1 interconnected with one another forming a network, thereby widening the intercellular spaces, which accomodated many lymphocytes (Fig. 8).

The reaction with PKK2 was almost identical to that with PKK1. In the surface epithelium, only the basal 


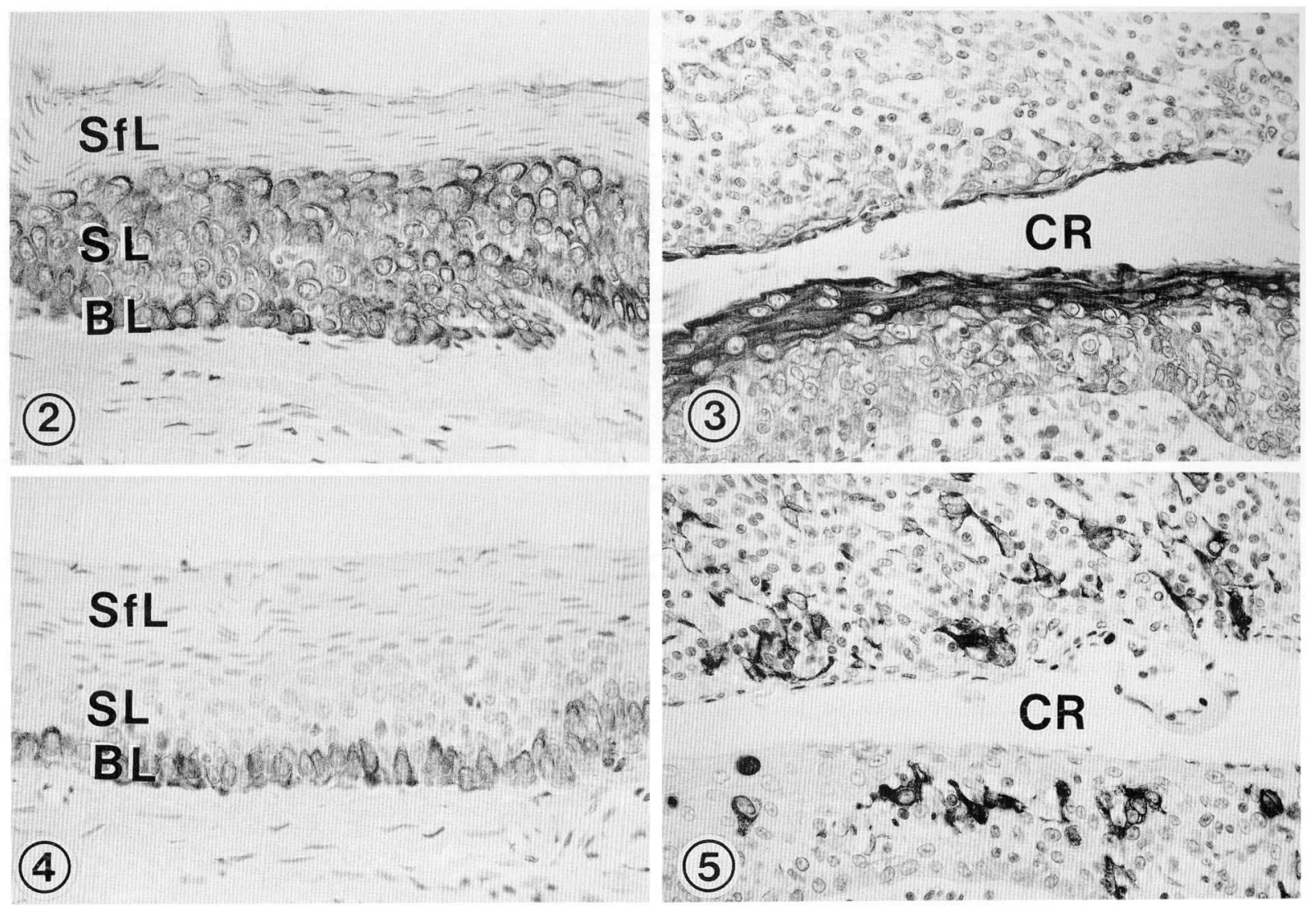

Figs. 2-5. Immunohistochemical reaction with polyclonal (K) (Figs. 2, 3) and monoclonal (PKK1) (Figs. 4, 5) antikeratin antibodies. Counterstaining with hematoxylin. Fig. 2. Epithelial cells of the spinous (SL) and the basal $(B L)$ layers in the surface epithelium are heavily stained with K. $\times 290$. Fig. 3 . All layers in the neck portion of the crypt $(C R)$ are stained with $\mathrm{K}, \times 260$. Fig. 4. Only the basal layer $(B L)$ of the surface epithelium displays a positive PKK1 immunoreaction. $\times 290$. Fig. 5. A few PKK1-positive cells are scattered in the spinous layer of the neck portion of the crypt $(C R)$. $S f L$ superficial layer. $\times 260$

layer reacted with PKK2. No reaction was observed in the suprabasal layers. In the crypt epithelium, densely stained epithelial cells with long cytoplasmic processes encompassed the cavity around the lymphocytes (Fig. 9).

\section{Light microscopy of semithin sections}

Semithin sections stained with toluidine blue were useful to clarify the complex relation between the lymphocytes and the epithelial cells, which was obscure in the hematoxylin-eosin preparations.

A number of small, medium-sized and large lymphocytes infiltrated the crypt epithelium. The large lymphocytes, with cear nuclei and abundant cytoplasm, were recognized in the basal layer and the lower part of the spinous layer. The small lymphocytes were located throughout all layers.

A few lymphocytes joined together to form nests in the spinous layer in the crypt neck. A cavity frequently occurred around these lymphocytes; this was encompassed by the tranformed epithelial cells with prolonged cytoplasmic processes (Fig. 10). Other epithelial cells in the spinous layer remained polygonal in shape. The transformed epithelial cells adhered to one another by forming intercellular bridges, which extended over the entire cell surface except for the luminal surface. The lymphocytes in the cavity were small or medium-sized. The size of the cavity was not in a clear quantitative relationship to the number of the lymphocytes included. A large cavity formed around each cluster of small lymphocytes character- 


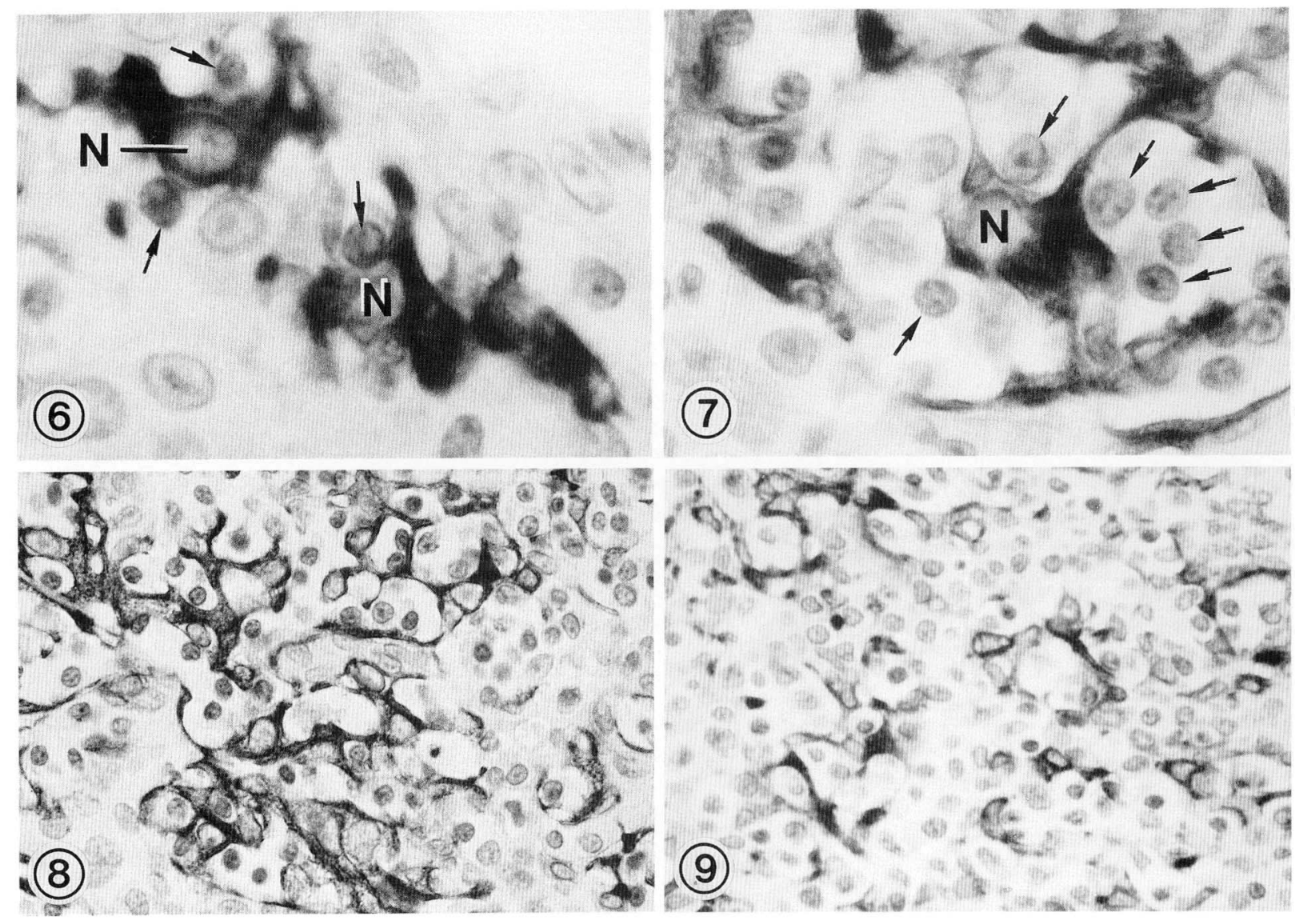

Figs. 6-9. Immunohistochemical reaction with PKK1 (Figs. 6-8) and PKK2 (Fig. 9). Counterstaining with hematoxylin. Fig. 6. Higher magnification of PKK1-positive cells in the neck portion of the crypt. Epithelial cells adjacent to lymphocytes (arrows) are heavily stained with PKK1, and emit cytoplasmic processes. $\times 1,300$ Fig. 7. PKK1-positive, transformed epithelial cells in the crypt epithelium surround cavities occupied by clusters of infiltrating lymphocytes (arrows). $N$ nucleus of the PKK1-positive epithelial cell. $\times 1,300$. Fig. 8. Deep portion of the crypt. PKK1-positive, transformed epithelial cells interconnect with one another forming a network of reticulum cells. Numerous lymphocytes invade the widened intercellular spaces. $\times 450$. Fig. 9. PKK2positive, transformed epithelial cells encompass cavities around lymphocytes in the crypt epithelium. $\times 450$

ized by dark round nuclei with condensed heterochromatin. The cavity also contained degenerating lymphocytes or pyknotic lymphocytes and fragments of the cell debris lightly stained with toluidine blue.

The basement membrane of the surface epithelium continuously bordered the stratified squamous epithelium, but was disrupted in the crypt epithelium where lymphocytes were shown to invade.

Intraepithelial blood capillaries were found in the lower layers of the crypt epithelium. We could easily distinguish them from the cavity surrounding the lymphocytes because their lumen was delineated by endothelial cells.

\section{Electron microscopy}

The wall of the cavities containing lymphocytes observed under the electron microscope revealed epithelial cells bearing long processes. The cells were characterized by two surfaces; the luminal surface projected discrete microvilli into the cavity, while the opposite cell surface was decorated with desmosomal attachments to the neighboring epithelial cells (Fig. 11). The surface of lymphocytes in the cavity showed a wavy appearance with a small number of microvilli. Some of them possessed well developed pseudopods. The lumen of the cavity was filled with amorphous 


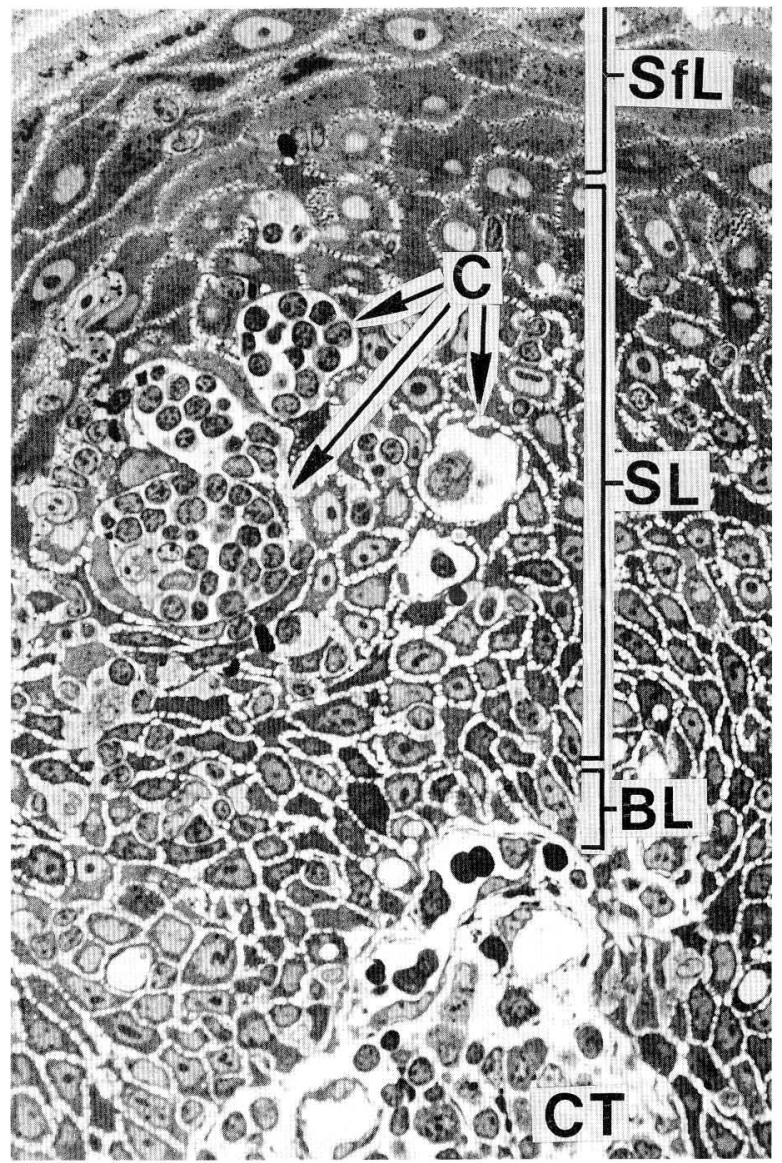

Fig. 10. Stratified squamous epithelium in the neck portion of the crypt. Note cavities $(C)$ with clusters of infiltrating lymphocytes. Transformed epithelial cells surround the cavities with their long cytoplasmic extensions. Semithin Epon section stained with toluidine blue. $B L$ basal layer, $C T$ connective tissue, $S f L$ superficial layer, $S L$ spinous layer. $\times 560$ electron-lucent materials (Fig. 11). The epithelio-epithelial intercellular space near the cavities was also extended where microvilli of the epithelial cells grew, and it also contained electron-lucent materials. The long epithelial processes were connected with those of neighboring cells by desmosomes, and bundles of $10-\mathrm{nm}$ filaments were tightly anchored to the desmosomes (Fig. 11, upper inset). The $10 \mathrm{~nm}$ filaments were oriented to the longitudinal axis of the processes. Some lymphocytes emitted pseudopods into the intercellular spaces via interstices between the attenuated cytoplasmic processes of epithelial cells (Fig. 11, lower inset).

In the early stage of lymphocyte infiltration, intercellular clefts between the lymphocytes and epithelial cells were extremely close together, the narrowest site being about $25-30 \mathrm{~nm}$ in width (Fig. 12). As the intercellular spaces widened, the lymphocytes attached themselves to the surrounding epithelial cells by narrow tips of short cytoplasmic protrusions, while the lymphocytes were almost drawn apart from the epithelial cells (Figs. 13, 14). The surface of the epithelial cells facing the lymphocytes was comparatively smooth, losing the intercellular bridges. Such epithelial cells were elongated and extended their cytoplasm around the lymphocytes; bundles of numerous 10-nm filaments were observed in these processes (Figs. 13, 14).

In the deep portion of the crypt, where numerous intraepithelial lymphocytes were seen, the epithelial cells underwent striking changes in shape. They came to display elliptic nuclei with prominent nucleoli, a narrow cytoplasm, and very long attenuated cytoplasmic processes (Fig. 15). The long thread-like processes were connected with one another by small desmosomes, assuming a lacy appearance (Fig. 16). The dilated intercellular spaces were filled with amorphous electron-lucent materials, numerous lymphocytes, and a small number of plasma cells, macrophages and IDC-like cells.

Fig. 11. Electron micrograph showing cavities $\left(C_{1,2}\right)$ containing lymphocytes $\left(L_{1,2}\right)$ and adjacent epithelial cells $\left(E_{1-4}\right)$ in the neck portion of the crypt. The luminal surface of the transformed epithelial cells $\left(E_{1,3,4}\right)$, which are connected with the neighboring epithelial cells by desmosomes, bears discrete microvilli (arrows). $E_{1}$ an epithelial cell, crescent shaped and endowed with an elongated nucleus containing a prominent nucleolus. $E_{2}$ an epithelial cell retaining its polygonal shape, still contributes toward circumscribed portions of the wall cavities $\left(C_{1}\right.$ and $\left.C_{2}\right) . E_{3}$ an epithelial cell emitting two cytoplasmic processes, which surround cavities $C_{1}$ and $C_{2} . E_{4}$ an elongated epithelial cell, its cytoplasmic extension enfolding a cavity $C_{2}$. These epithelial cells $\left(E_{1-4}\right)$ are rich in keratin filaments. $L_{1}$ lymphocyte forming a pseudopod (asterisk). $L_{2}$ lymphocyte containing an invaginated nucleus. Wide intercellular spaces $(I S)$ adjacent to the cavity. $R B C$ red blood cell. $\times 5,000$. Upper inset: Attenuated cytoplasmic processes interconnected by desmosomes; note $10 \mathrm{~nm}$ keratin filaments converging at the desmosomes. $C$ cavity. $\times 21,000$. Lower inset: A lymphocyte $(L)$ protruding a long pseudopod (asterisk) via the interstices between epithelial cells $(E) . \times 9,200$ 


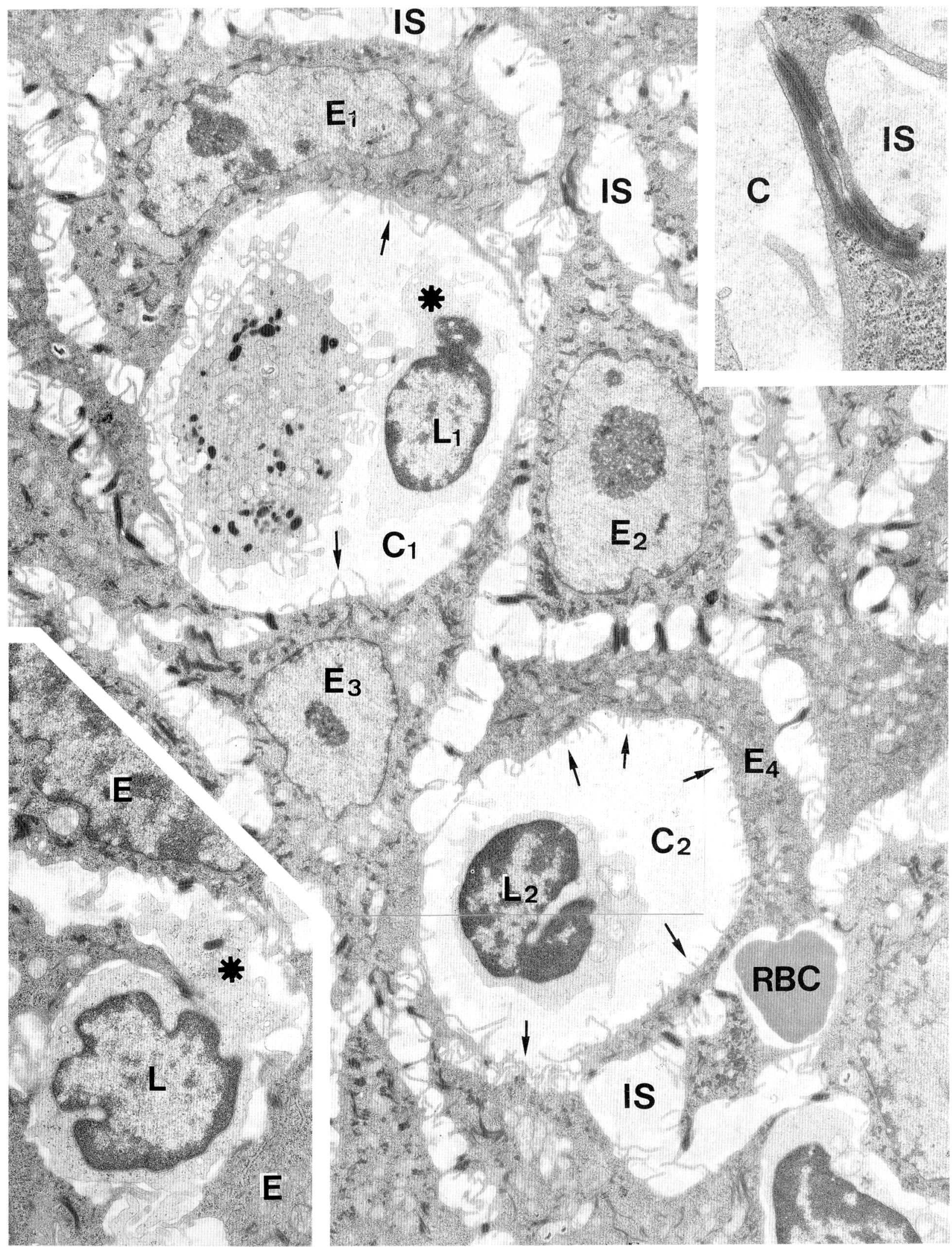

Fig. 11. Legend on the opposite page. 


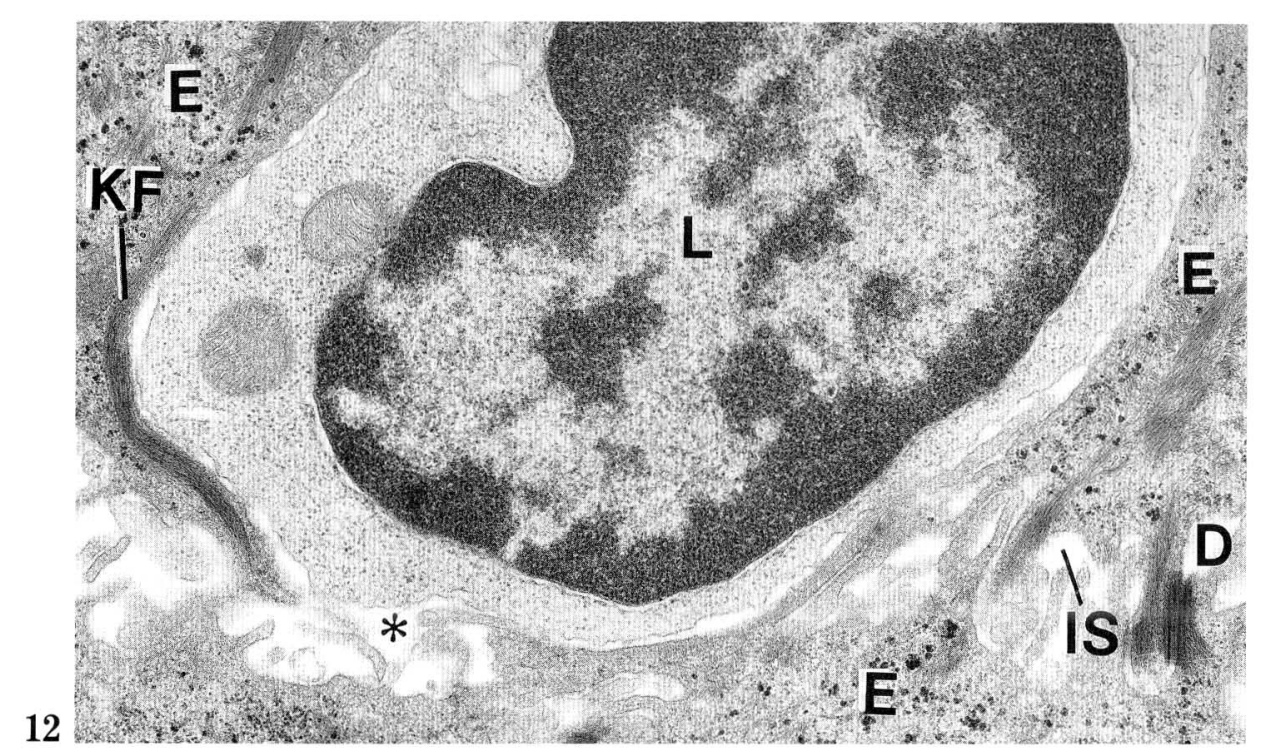

\section{3}
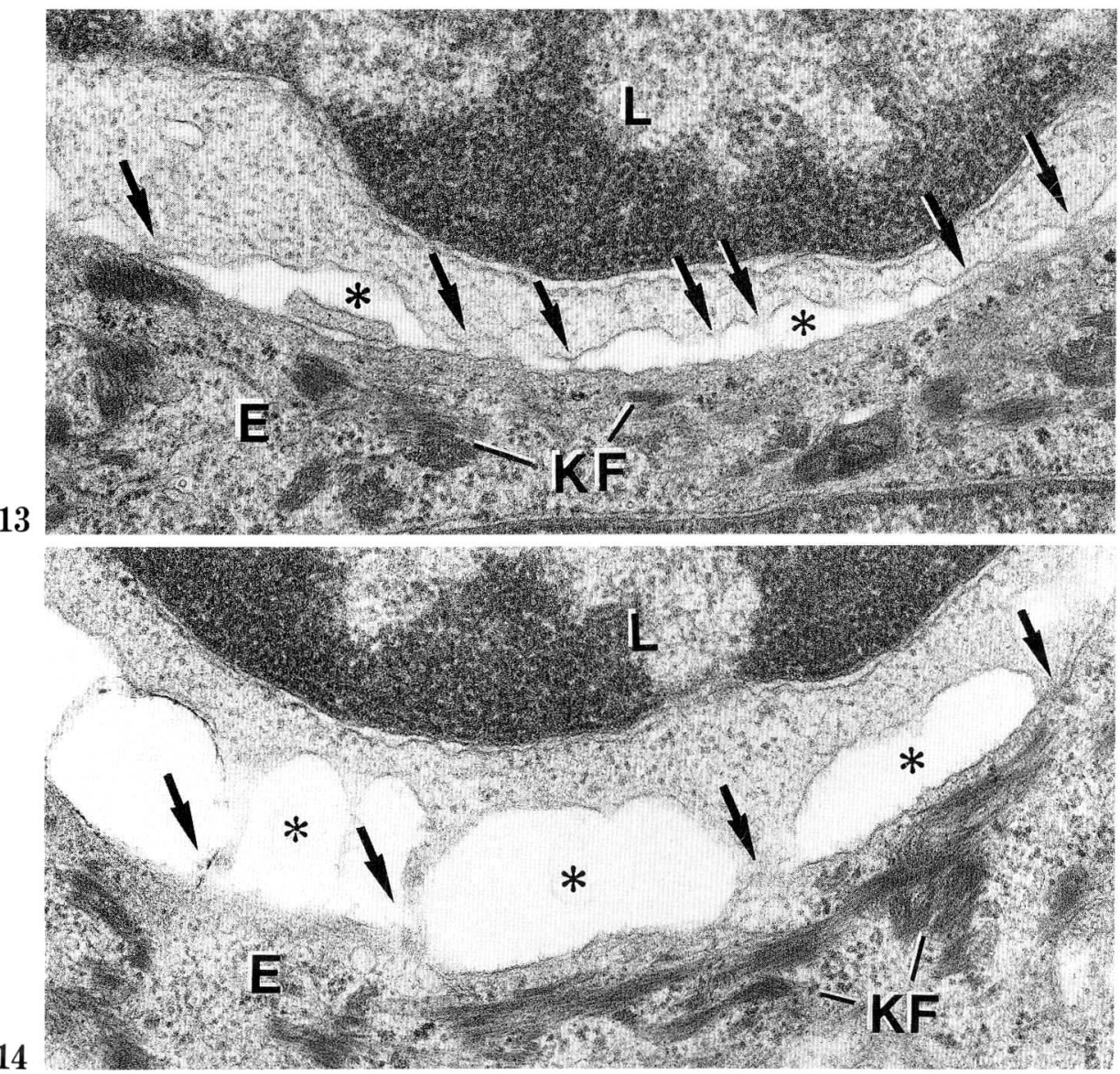

Figs. 12-14. Electron micrographs showing the relationship between lymphocytes $(L)$ and epithelial cells $(E)$; note the early stages of cavities surrounding lymphocytes. Fig. 12. A lymphocyte $(L)$ in close contact with the cytoplasm of epithelial cells $(E) . \times 15,000$. Fig. 13. Higher magnification of the lymphocyte-epithelial cell contact. Cytoplasmic membranes of both cells adhere in circumscribed areas (arrows) with extracellular threadlike materials. $\times 31,000$. Fig. 14. Cytoplasmic protrusions of a lymphocyte extend, and wider intercellular spaces (asterisks) are formed. Adhesions of the cytoplasmic membranes of the two cells still visible (asterisks). $D$ desmosome, $I S$ intercellular space, $K F$ keratin filaments. $\times 31,000$ 


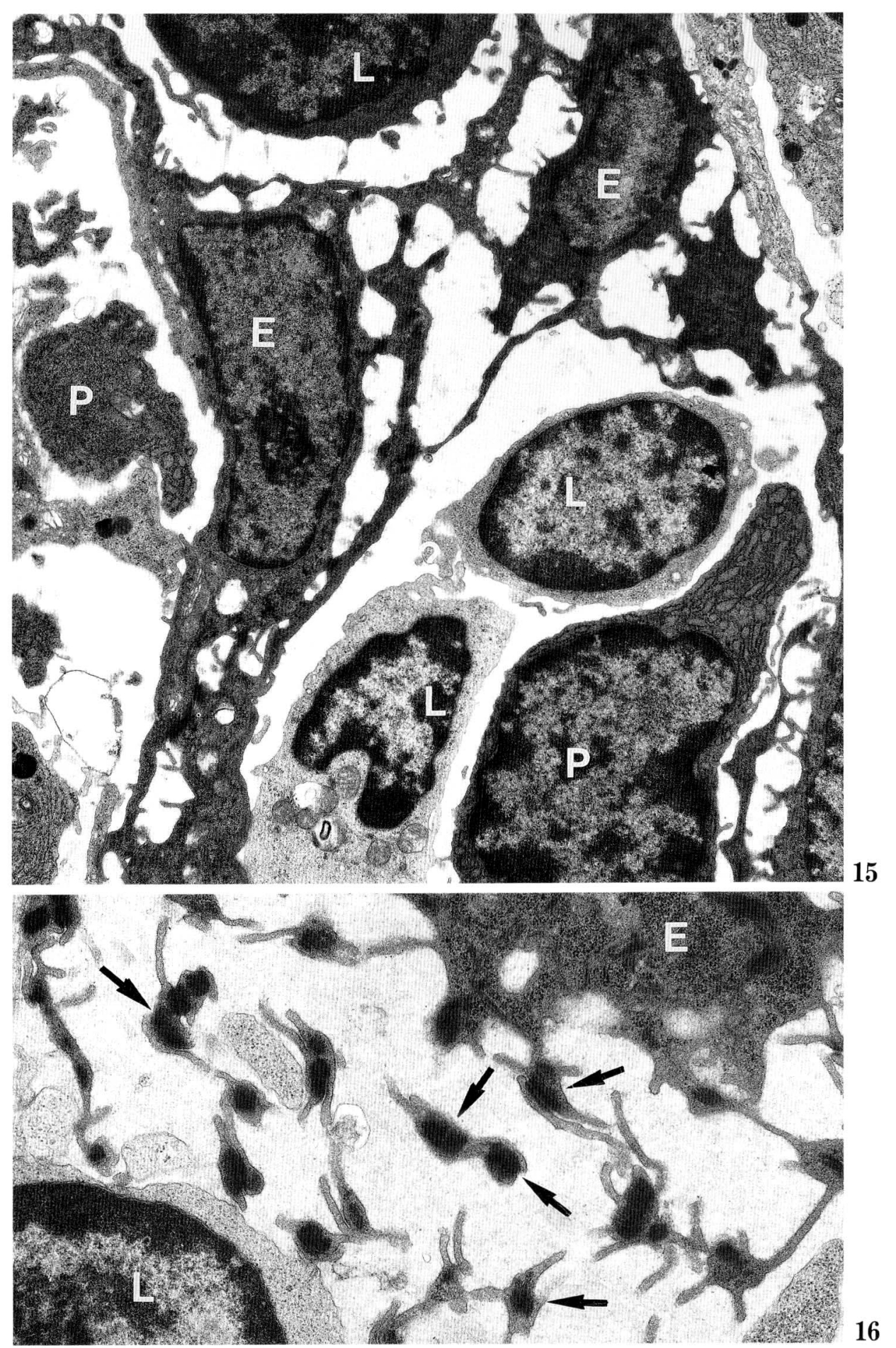

Figs. 15 and 16. Electron micrographs of epithelial reticulum cells $(E)$ in the deep portion of the crypt. Fig. 15. Epithelial reticulum cells $(E)$ interconnect via long thread-like cytoplasmic processes. The widened intercellular spaces are occupied by lymphocytes $(L)$, plasma cells $(P)$, and an amorphous electron-lucent material. $\times 7,200$. Fig. 16. Attenuated cytoplasmic processes of epithelial reticulum cells $(E)$ containing keratin filaments interlock with one another by means of small desmosomes (arrows). $\times 14,000$ 


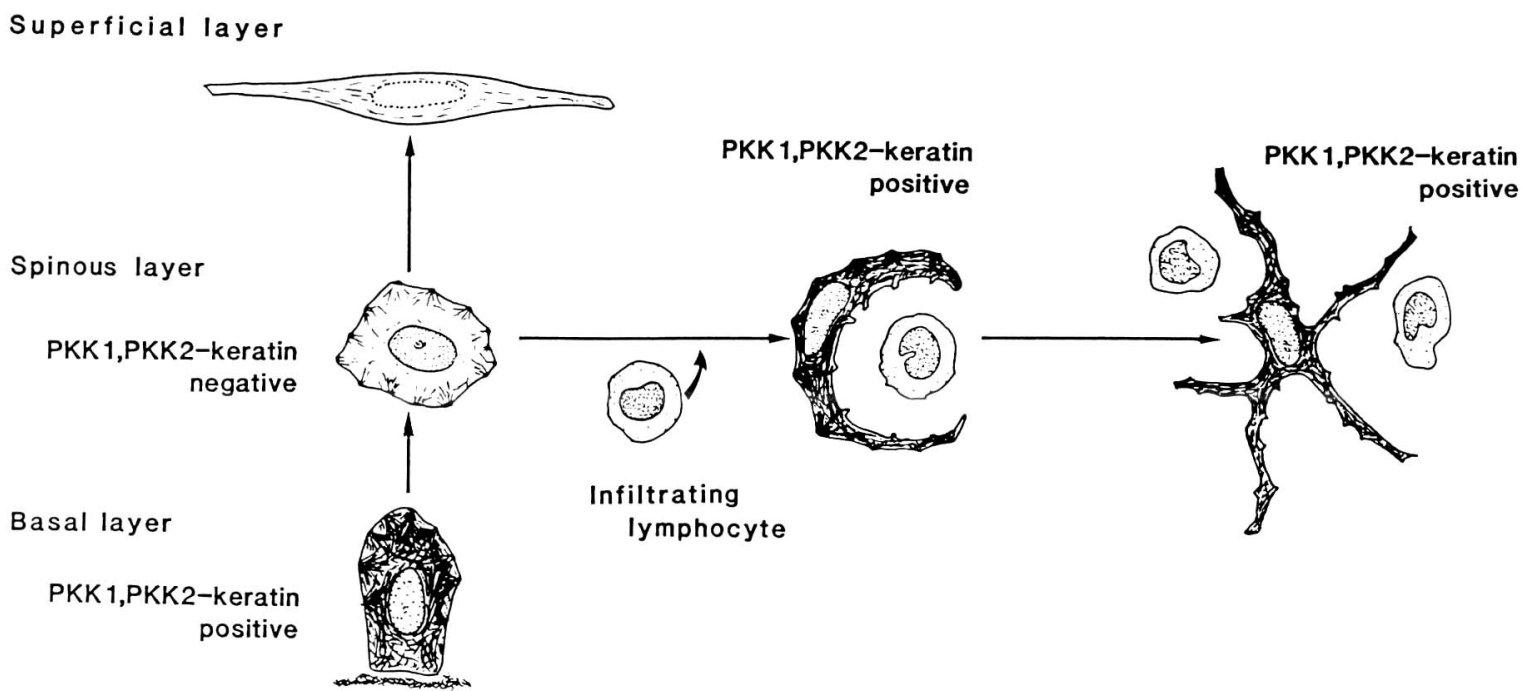

Fig. 17. Proposed interpretation of the change in cytokeratin expression and cell shape during the infiltration of lymphocytes. Conventional epithelial cells of the spinous layer do not contain PKK1, PKK2-keratin. The epithelial cells of the crypt transform into elongated or star-shaped cells containing PKK1, PKK2-keratin by lympho-epithelial interaction.

\section{DISCUSSION}

The present immunohistochemical study mainly used ethanol-fixed sections. Formalin fixations gave a poor immunoreactivity and frozen sections did not show a satisfactory morphology despite well preserved immunoreactivity. Ethanol fixation was most favorable for the demonstration of cytokeratin (ALTMANSBERGER et al., 1981; HUiTfELdT and BRANDZAEG, 1985).

The cytokeratin composition in the basal layer of the stratified squamous epithelium varies by animal species, tissue type and organ (MURASE et al., 1986). In human epidermis, PKK1 does not react with basal and suprabasal cells; it reacts only with hair follicle epithelial and glandular cells (VIRTANEN et al., 1985). On the other hand, in the buccal mucosa of the hamster, guinea pig and rabbit, PKK1 reacts with the basal cells (MURASE et al., 1986). Our observations show that PKK1-cytokeratin is present in the basal layer of the surface epithelium of human palatine tonsils as well as in the epithelial cells of whole layers of the deep crypt. PKK2, which specifically stains the basal layer of the human epidermis (VIRTANEN et al.,
1985), demonstrates almost the same immunoreaction as PKK1 in our materials. Since PKK1 corresponds to cytokeratin No. 19, 18, 8 and PKK2 to No. 19, 17, 7 (HOLTHÖFER et al., 1983, 1984; VIRTANEN et al., 1985; GUSTAFSSON et al., 1988), the main cytokeratin component may be No. 19, which reacts with both antibodies in our study.

The cytokeratin composition of a given epithelium varies depending on the course of differentiation in the human epidermis (FUCHS and GREEN, 1980; WOODCOCKMitchell et al., 1982) or the cellular growth environment (FRANKE et al., 1981; BOHNERT et al., 1986; MOLLOY and LASKIN, 1988). The present study shows that in the spinous layer of the neck portion of the crypt, stellate or elongated epithelial cells enfolding lymphocytes display immunoreactivities to PKK1 and PKK2. They contain $10-\mathrm{nm}$ filaments and adhere to neighboring PKK1- and PKK2-negative epithelial cells by desmosomes. Various transitional forms can be observed between such cells in the neck portion and the PKK1and PKK2-positive epithelial reticulum cells in the deep portion of the crypt. It thus appears reasonable to conclude that the PKK1- and PKK2-positive, transformed epithelial cells are derived from conventional 
polygonal epithelial cells of the spinous layer, which react with polyclonal antikeratin antibody $\mathrm{K}$ and do not express PKK1- and PKK2-cytokeratin.

There is a question as to whether the transformation of the epithelial cells with PKK1- and PKK2-cytokeratin first occurs and then the lymphocytes infiltrate the crypt epithelium, or, obversely following the infiltration of lymphocytes, the epithelial cells are transformed expressing PKK1- and PKK2-cytokeratin. It is likely, however, that the change in keratin phenotype and cell shape occurs after the infiltration of lymphocytes according to our following immunohistochemical and ultrastructural observations: 1) Only those epithelial cells which are juxtaposed with the infiltrating lymphocytes are irregularly-shaped cells with PKK1- and PKK2-cytokeratin (Figs. 6-9), and 2) several steps occur in the relationship between the lymphocytes and the epithelial cells, i.e., from the close contact of both cells (Fig. 12), through the stages of the developing intercellular spaces (Figs. 13, 14), to the cavity formation around the lymphocyte enfolded by the transformed epithelial cells (Fig. 11). Recently it has been reported that the products of $T$ cells, such as Interleukin 3 (IL-3), the granulocyte/macrophage colony stimulating factor (GM-CSF), Interferon $\gamma$ (INF- $\gamma$ ) and the transforming growth factor $\beta$ (TGF$\beta$ ), regulate keratinocyte growth and differentiation (HANCOCK et al., 1988). Although a subset of lymphocytes invading the crypt epithelium cannot be identified in the present study, it is possible that some lymphokines released from the lymphocytes play a role in the transformation and change in keratin phenotype of the tonsillar epithelial cells.

The close relationship between lymphocytes and a special type of epithelial cells, called $M$ cells, has also been reported in the palatine tonsils (OLAH and EVERETTE, 1975; SuRJAN, 1980; HOWIE, 1980; KARCHEV and KABAKCHIEV, 1982). The features of M cells in the palatine tonsils in the literature are as follows: 1 ) Surface microvilli replace microfolds, 2) thin and prolonged cytoplasmic processes enfold lymphocytes, 3 ) well-developed vesicles and vacuoles occur in the cytoplasm, 4) the connection with neighboring epithelial cells is established by desmosomes, and 5) the distribution is restricted to the surface area exposed to the crypt lumen. In our materials, the PKK1- and PKK2-positive cells were distributed throughout the epithelium constituting the network of reticular elements, and not restricted to the surface of the crypt epithelium. Moreover, they were poor in vesicular inclusions.Except for the above characteristics, the PKK1- and PKK2-positive epithelial cells are very similar to $\mathrm{M}$ cells in the palatine tonsils, since the
PKK1- and PKK2-positive cells enfolding the lymphocytes are elongated and possess long cytoplasmic processes, microvilli on the luminal surface, and desmosomal attachments to neighboring epithelial cells. To date, cytokeratin has not been detected in $\mathrm{M}$ cells. The possibility that some of the PKK1- and PKK2-positive epithelial cells displaying close contact with lymphocytes may differentiate into $M$ cells is, however, open to discussion.

Cell resembling interdigitating cells (IDC-like cells) within the crypt epithelium are another specialized cell type which shows intimate contact with lymphocytes (VON GAUDECKER and MÜLLER-HERMELINK, 1982; VON GAUDECKER et al., 1984). IDC-like cells display irregularly shaped nuclei and a translucent cytoplasm, and extends cytoplasmic projections. They do not have microvilli on the surface membrane, and their irregular cytoplasmic outlines interdigitate with neighboring lymphocytes. Such morphological features do not correspond to the PKK1- and PKK2positive transformed epithelial cells. Moreover, the IDC-like cells are thought to be of non-epithelial origin (VON GAUDECKER and MÜLLER-HERMELINK, 1982).

The microenvironment of the thymus is essential for the T-cell maturation process, and heterogeneous populations of thymic epithelial cells have been reported (VAN DE WIJINGAERT et al., 1984; NiCOLAS et al., 1985, 1986; VON GAUDECKER et al., 1986; USHIKI, 1986; KANESHIMA et al., 1987). Particularly, thymic nurse cells (TNC) isolated from tissue fragments by enzymatic digestions display morphologically visible lymphoepithelial interactions (WEKERLE et al., 1980; KYEWSKI, 1986). Although it is still a matter of controversy whether they exist in vivo morphologically in the same form as in vitro (WEISSMAN, 1986), there are some reports that TNC are derived from a special type of cortical epithelial cells (RITTER et al., 1981; VAN DE WIJNGAERT et al., 1983, 1984; LEENE et al., 1988). Since the putative TNC in vivo send cytoplasmic extensions between lymphocytes, and in some sections surround lymphocytes (VAN DE WIJN GAERT et al., 1983, 1984), they are morphologically similar to the PKK1- and PKK2-positive transformed epithelial cells in the palatine tonsils. Epithelial-like cells containing lymphocytes have been isolated in human adenoids and tonsils (MANCONI et al., 1984). As for ontogenetic differentiation, there are several similarities between the thymus and the palatine tonsils (VON GAUDECKER and MÜLLER-HERMELINK, 1980, 1982), and the crypt epithelium of the palatine tonsils serves as the T-cell region (YAMANAKA et al., 1983; VON GAUDECKER et al., 1984). In addition, kera- 
tinocytes in the epidermis have been demonstrated to produce IL-1, IL-6, IL3-like cytokine and GM-CSF, which induce the proliferation of $\mathrm{T}$ cell lines and regulate the immune response in the epidermis (LUGER et al., 1981, 1985; MIOSSEC et al., 1984; DUSTIN et al., 1986; KUPPER et al., 1986, 1988a, b). In these respects, it is not unlikely that the similar lymphoepithelial interactions occur in the crypt epithelium in the palatine tonsils.

In conclusion, the infiltration of lymphocytes into the crypt epithelium may induce the change in keratin expression, i.e., PKK1- and PKK2-negative cells in the spinous layer of the surface epithelium are changed into PKK1- and PKK2-positive cells in the same layer of the crypt epithelium. This change in keratin phenotype apparently causes the epithelial cells to differentiate into star-shaped reticular elements. Figure 17 shows a schematic interpretation of the relation between the lymphocyte and the tonsillar epithelial cell. Nonetheless, the questions of what subpopulations of lymphocytes affect the neighboring epithelial cells and whether these lymphocytes release a local chemical mediator to which the epithelial cells respond require further investigation.

Acknowledgements. The authors wish to thank Dr. Toshiharu Matsumoto and Mr. Hiroshi ABE, Department of Pathology, University of Juntendo, for their technical advice on immunohistochemical reactions.

\section{REFERENCES}

Altmannsberger, M., M. Osborn, A. Schauer and K. WEBER: Antibodies to different intermediate filament proteins. Cell type-specific markers on paraffin-embedded human tissues. Lab. Invest. 45: 427-434 (1981).

BEN-ZE'Ev, A.: Differential control of cytokeratins and vimentin synthesis by cell-cell contact and cell spreading in cultured epithelial cells. J. Cell Biol. 99: 1424-1433 (1984).

Bohnert, A., J. Hornung, I. C. Mackenzie and N. E. Fusenig: Epithelial-mesenchymal interactions control basement membrane production and differentiation in cultured and transplanted mouse keratinocytes. Cell Tiss. Res. 244: 413-429 (1986).

Brandtzaeg, P.: Immunobarriers of the mucosa of the upper respiratory and digestive pathways. Acta Otolaryngol. 105: 172-180 (1988).

Cooper, D., A. Schermer and T.-T. Sun : Biology of disease. Classification of human epithelial and their neoplasms using monoclonal antibodies to keratins: Strategies, applications and limitations. Lab. Invest. 52: 243-256 (1985).
Dustin, M. L., R. Rothlein, A. K. Bhan, C. A. Dinar ELlo and T. A. Springer: Induction by IL-1 and interferon- $\gamma$ : tissue distribution, biochemistry, and function of a natural adherence molecule (ICAM-1). J. Immunol. 137: 245-254 (1986).

Dustin, M. L., K. H. Singer, D. T. Tuck and T. A., SPRINGER: Adhesion of T lymphoblasts to epidermal keratinocytes is regulated by interferon $\gamma$ and is mediated by intercellular adhesion molecule 1 (ICAM-1) J. Exp. Med. 167: 1323-1340 (1988).

Franke, W. W., E. Schmid, D. L. Schiller, S. Winter, E. D. JaRasch, R. Moll, H. Denk, B. W. JACKson and K. ILLMENSEE: Differentiation-related patterns of expression of proteins of intermediate-size filaments in tissues and cultured cells. Cold Spring Harbor Symp. Quant. Biol. 46: 431-453 (1981).

Fuchs, E. and H. Green: Changes in keratin gene expression during terminal differentiation of the keratinocyte. Cell 19: 1033-1042 (1980).

GAUdeCKER, B. voN and H. K. MÜLleR-HermelinK: Ontogeny and organization of the stationary nonlymphoid cells in the human thymus. Cell Tiss. Res. 207: 287-306 (1980).

- The development of the human tonsilla palatina. Cell Tiss. Res. 224: 579-600 (1982).

Gaudecker, B. von, U. Pfingsten and H. K. MüllerHeRMELINK: Localization and characterization of $T$ cell subpopulations and natural killer cells $\left(\mathrm{HNK} 1^{+}\right.$ cells) in the human tonsilla palatina. An ultrastructuralimmunocytochemical study. Cell Tiss. Res. 238: 135-143 (1984).

Gaudecker, B. von, G. C. Steinmann, M. L. Hansmann, J. HARPPREChT, M. M. MiliceviC and H. K. MüLlerHeRmelink: Immunohistochemical characterization of the thymic microenvironment. A light-microscopic and ultrastructural immunocytochemical study. Cell Tiss. Res. 244: 403-412 (1986).

Gustafsson, H., U. KJörell, A. Eriksson, I. Virtanen and L.-E. THORNELL: Distribution of intermediate filament proteins in developing and adult salivary glands in man. Anat. Embryol. 178: 243-251 (1988).

Hancock, G. E., G. KaPlan and Z. A. Cohn: Keratinocyte growth regulation by the products of immune cells. J. Exp. Med. 168: 1395-1402 (1988).

Haynes, B. F.: The human thymic microenvironment. Adv. Immunol. 36: 87-142 (1984).

Holthöfer, H., A. Miettinen, R. PaAsivuo, V.-P. Lehto, E. Linder, 0. Alfthan and I. Virtanen: Cellular origin and differentiation of renal carcinomas: a fluorescence microscopic study with kidney-specific antibodies, antiintermediate filament antibodies, and lectins. Lab. Invest. 49: 317-326 (1983).

Holthöfer, H., A. Miettinen, V.-P. Lehto and I. Virtanen: Expression of vimentin and cytokeratin types of intermediate filament proteins in developing and adult human kidneys. Lab. Invest. 50: 552-559 (1984).

Hosaka, M., N. Murase, S. Fukui and M. Mori: Differential distribution of immunohistochemically detected 
keratin proteins in mammalian oral epithelia. Acta Anat. 123: 125-130 (1985).

Howie, A. J.: Scanning and transmission electron microscopy on the epithelium of human palatine tonsils. J. Pathol. 130: 91-98 (1980).

Hsu, S. M., L. RAINE and H. FANGER: Use of avidin-biotinperoxidase complex $(\mathrm{ABC})$ in immunoperoxidase techniques: a comparison between $\mathrm{ABC}$ and unlabeled antibody (PAP) procedures. J. Histochem. Cytochem. 29: 577-580 (1981).

HuitfeldT, H. S. and P. Brandtzaeg: Various keratin antibodies produce immunohistochemical staining of human myocardium and myometrium. Histochemistry 83: 381-389 (1985).

Kaneshima, H., M. Ito, J. Asai, O. Taguchi and H. HIAI: Thymic epithelial reticular cell subpopulations in mice defined by monoclonal antibodies. Lab. Invest. 56: 372-380 (1987).

KARCHEV, T. and P. KABAKChIEv: Electron-microscope observations on the tonsillar epithelium in children with recurrent tonsillitis. Int. J. Pediat. Otorhinolaryngol. 4: 149-156 (1982).

KasPer, M., R. Moll, P. StosieK and U. Karsten: Patterns of cytokeratin and vimentin expression in the human eye. Histochemistry 89: 369-377 (1988).

Kupper, T. S., D. W. Ballard, A. O. Chua, J. S. McGuire, P. M. Flood, M. C. HoRowitz, R. LANGDON, L. LIGHTFOOT and U. GUBLER: Human keratinocytes contain mRNA indistinguishable from monocyte interleukin $1 \alpha$ and $\beta$ mRNA. J. Exp. Med. 164: 2095-2100 (1986).

Kupper, T. S., L. MaY, N. Birchall and P. Behgal: A cytokine which can provide a 2nd signal in the activation of T cells. J. Invest. Dermatol. 90: 578 (1988a).

Kupper, T. S., F. Lee, D. Coleman, J. Chodakewitz, P. Flood and M. Horowitz: Keratinocyte derived T-cell growth factor (KTGF) is identical to granulocyte macrophage colony stimulating factor (GM-CSF). J. Invest. Dermatol. 91: 185-188 (1988b).

KYEWSKI, B. A.: Thymic nurse cell: possible sites of T-cell selection. Immunol. Today 7: 374-379 (1986).

Leene, W., R. De WaAl MalefiJt, P. J. M. Roholl and K. A. Hoeben: Lymphocyte depletion in thymic nurse cells: a tool to identify in situ; lympho-epithelial complexes having thymic nurse cell characteristics. Cell Tiss. Res. 253: 61-68 (1988).

LUGER, T. A., B. M. STADleR, S. I. KATZ and J. J. OPPENHeiM: Epidermal cell (keratinocyte)-derived thymocyte-activating factor (ETAF). J. Immunol. 127: 1493-1498 (1981).

LugER, T. A., U. WirTh and A. Köck: Epidermal cells synthesize a cytokine with interleukin 3-like properties. J. Immunol. 134: 915-919 (1985).

Manconi, P. E., M. G. Ennas, M. R. Murru, G. Cadeddu, G. ToRE and M. S. LANTINI: Epithelial-like cells containing lymphocytes (nurse cells) in human adenoids and tonsils. Thymus 6: 351-357 (1984).

Miossec, P., C.-L. YU and M. ZIFF: Lymphocyte chemotactic activity of human interleukin 1. J. Immunol. 133: 2007-2011 (1984).
Moll, R., W. W. Franke, D. L. Schiller, B. Geiger and R. KREPLER: The catalog of human cytokeratins: patterns of expression in normal epithelia, tumors, and cultured cells. Cell 31: 11-24 (1982).

Molloy, C. J. and J. D. LASkIN : Keratin polypeptide expression in mouse epidermis and cultured epidermal cells. Differentiation 37: 86-97 (1988).

Murase, N., S. Fukui and M. Mori: Heterogeneity of keratin distribution in the oral mucosa and skin of mammals as determined using monoclonal antibodies. Histochemistry 85: 265-276 (1986).

NaKane, P. K.: Recent progress in the peroxidase-labeled antibody method. Ann. New York. Acad. Sci. 254: 203211 (1975).

Nicolas, J. F., W. Savino, A. Reano, J. Viac, J. Brochier and M. DARDENnE: Heterogeneity of thymic epithelial cell (TEC) keratins. Immunohistochemical and biochemical evidence for a subset of highly differentiated TEC in the mouse. J. Histochem. Cytochem. 33: 687-694 (1985).

Nicolas, J. F., A. Reano, D. Kaiserlian and J. Thivolet: Epithelial cell heterogeneity in the guinea pig thymus: immunohistochemical characterization of four thymic epithelial subsets defined by monoclonal antikeratin antibodies. Eur. J. Immunol. 16: 457-464 (1986).

OLAH, I. and N. B. EveretTe: Surface epithelium of the rabbit palatine tonsil: Scanning and transmission electron microscopic study. J. Reticuloendothel. Soc. 18: 5362 (1975).

Osborn, M. and K. Weber: Biology of disease. Tumor diagnosis by intermediate filament typing: a novel tool for surgical pathology. Lab. Invest. 48: 372-394 (1983).

Quinlan, R. A., D. L. Schiller, M. Hatzfeld, T. Achtstätter, R. Moll, J. L. Jorcano, T. M. Magin and W. W. Franke: Patterns of expression and organization of cytokeratin intermediate filaments. Ann. New York Acad. Sci. 455: 282-306 (1985).

Ritter, M. A., C. A. Sauvage and S. F. Cotmore: The human thymus microenvironment: in vitro identification of the thymic nurse cells and other antigeneticallydistinct subpopulations of epithelial cells. Immunology 44: 439-446 (1981).

Schlegel, R., S. Banks-Schlegel and G. S. Pinkus: Immunohistochemical localization of keratin in normal human tissues. Lab. Invest. 42: 91-96 (1980).

Shiohara, T., N. MoriYa and M. Nagashima: The lichenoid tissue reaction. A new concept of pathogenesis. Int. J. Dermatol. 27: 365-374 (1988).

SuRJấ, L., Jr.: Reduced lymphocyte activation in repeatedly inflamed human tonsils. Acta Otolaryngol. 89: 187-194 (1980).

Tseng, S. C. G., M. J. Jarvinen, W. G. Nelson, J.-W. Huang, J. Woodcock-Mitchell and T.-T. Sun: Correlation of specific keratins with different types of epithelial differentiation: Monoclonal antibody studies. Cell 30: 361-372 (1982).

UshikI, T.: A scanning electron-microscopic study of the rat thymus with special reference to cell types and 
migration of lymphocytes into the general circulation. Cell Tiss. Res. 244: 285-298 (1986).

Viebahn, C., E. B. LANe and F. C. S. Ramaekers: Keratin and vimentin expression in early organogenesis of the rabbit embryo. Cell Tiss. Res. 253: 553-562 (1988).

Virtanen, I., M. Miettinen, V.-P. Lehto, A. L. Kar INIEMI and R. Passivuo: Diagnostic application of monoclonal antibodies to intermediate filaments. Ann. New York Acad. Sci. 455: 635-648 (1985).

W Aal MalefiJt, R. DE, W. LeEne, P. J. M. Roholl, J. WORMMEester and $\mathbf{K}$. A. HoEBEN: T cell differentiation within thymic nurse cells. Lab. Invest. 55: 25-34 (1986).

Weissman, I. L.: Nursing the thymus. Lab. Invest. 55: 1-4 (1986).

WeKerLe, H., U.-P. Ketelsen and M. ERNST: Thymic nurse cell. Lymphoepithelial cell complexes in murine thymus: morphological and serological characterization. J. Exp. Med. 151: 925-944 (1980).

WiJngaert, F. P. van De, L. H. P. M. Rademakers, H.-J. SchuUrman, R. A. DE Weger and L. Kater: Identification and in situ localization of the "thymic nurse cell" in man. J. Immunol. 130: 2348-2351 (1983).

WiJngaert, F. P. VAN DE, M. D. Kendall, H.-J. Schuurman, L. H. P. M. Rademakers and L. Kater: Heterogeneity of epithelial cells in the human thymus. An ultrastructural study. Cell Tiss. Res. 237: 227-237 (1984).
Woodcock-Mitchell, J., R. EichNeR, W. G. NeLSON and T.-T. Sun: Immunolocalization of keratin polypeptides in human epidermis using monoclonal antibodies. J. Cell Biol. 95: 580-588 (1982).

Yamanaka, N., S. Sambe, Y. Harabuchi and A. Kataura: Immunohistological study of tonsil. Distribution of $\mathrm{T}$ cell subsets. Acta Otolaryngol. 96: 509-516 (1983).

Dr. Yoko Sato

Department of Otolaryngology

Faculty of Medicine

Tokyo Medical and Dental University

Yushima 1-5-45, Bunkyo-ku

Tokyo 113, Japan

佐藤葉子

113 東京都文京区湯島 1-5-45

東京医科歯科大学医学部

耳鼻咽喉科学教室 